\title{
Common Sensory Inputs and Differential Excitability of Segmentally Homologous Reticulospinal Neurons in the Hindbrain
}

\author{
Hisako Nakayama ${ }^{1}$ and Yoichi Oda ${ }^{2,3}$ \\ ${ }^{1}$ Division of Biophysical Engineering, Graduate School of Engineering Science, and ${ }^{2}$ Neuroscience Laboratories, Graduate School of Frontier Biosciences, \\ Osaka University, and ${ }^{3}$ Precursory Research for Embryonic Science and Technology, Toyonaka, Osaka 560-8531, Japan
}

In the hindbrain of zebrafish and goldfish, reticulospinal (RS) neurons are arranged in seven segments, with segmental homologs in adjacent segments. The Mauthner cell (M-cell) in the fourth segment (r4) is known to trigger fast escape behavior. Its serial homologs, MiD2 $\mathrm{cm}$ in $\mathrm{r} 5$ and MiD3 $\mathrm{cm}$ in r6, are predicted to contribute to this behavior, which can be evoked by head-tap stimuli. However, little is known about their input- output properties. Therefore, we studied afferent projections from the auditory posterior eighth nerve ( $\mathrm{pVIIIn)}$ and firing properties of $\mathrm{MiD} 2 \mathrm{~cm}$ and $\mathrm{MiD} 3 \mathrm{~cm}$ for comparison with the M-cell in adult goldfish. Labeling of RS neurons and the pVIIIn afferents with fluorescent tracers showed that the pVIIIn projected to $\mathrm{r} 4-\mathrm{r} 6$. Tone burst and electrical stimulation of the $\mathrm{pVIIIn}$ evoked EPSPs in the M-cell, MiD2cm, and MiD3cm. Stepwise depolarization typically elicited a single spike at the onset in the M-cell but repetitive spiking in MiD2 $\mathrm{cm}$ and MiD3cm. This atypical property of the M-cell was mediated by dendrotoxin-I (DTX-I)-sensitive voltage-gated potassium channels together with recurrent inhibition, because combined application of DTX-I, strychnine, and bicuculline led to continuous repetitive firing in M-cells. The M-cell but not MiD2 $\mathrm{cm}$ or MiD3cm expressed Kv1.2, a DTX-I-sensitive potassium channel subunit. Thus, the M-cell and its segmental homologs may sense common auditory information but send different outputs to the spinal circuits to control adaptive escape behavior.

Key words: Mauthner cell; reticulospinal neurons; segmental homologs; eighth nerve afferents; recurrent inhibition; dendrotoxin

\section{Introduction}

Vertebrate hindbrains are segmented structures. Seven clusters of reticulospinal (RS) neurons are periodically arranged along the neuraxis in the hindbrain of zebrafish and goldfish (Kimmel et al., 1982; Metcalfe et al., 1986; Lee and Eaton, 1991; Lee et al., 1993a) (see Fig. 1A1). RS neurons sharing a common morphology in adjacent segments are referred to as segmental homologs. The Mauthner cell (M-cell), MiD2 cm, and MiD3 $\mathrm{cm}$ are bilaterally paired RS neurons, located in $\mathrm{r} 4-\mathrm{r} 6$, respectively. These segmental homologs are collectively called the "Mauthner series" (M-series) (see Fig. 1A2). Each M-series neuron has two major dendrites and sends an axon to the contralateral spinal cord, with $\mathrm{M}$-cells having the largest cell body. In addition to their morphological similarities, the homologous neurons share common developmental and neurochemical properties (Mendelson, 1986a,b; Hanneman et al., 1988; Hanneman and Westerfield, 1989).

\footnotetext{
Received Sept. 30, 2003; revised Jan. 26, 2004; accepted Jan. 26, 2004.

This work was supported by grants-in-aid for scientific research to Y.0. We are grateful to Drs. E. S. Ruthazer (Cold Spring Harbor Laboratory, Cold Spring Harbor, NY), W.-J. Song, Y.Zhu, F. Murakami (Osaka University, Osaka, Japan), and N. Yamamoto (Nippon Medical School, Tokyo, Japan) for their helpful comments on this manuscript. We also thank N. Yamamoto for helpful advice on morphological analysis and H. Matsui, Y. Murakami, and Y. Kobashi for their collaboration in the early electrophysiological study.

Correspondence should be addressed to Dr. Yoichi Oda, Neuroscience Laboratories, Graduate School of Frontier Biosciences, Osaka University at Machikaneyama 1-3, Toyonaka, Osaka 560-8531, Japan. E-mail: oda@fbs.osaka-u.ac.jp. D0I:10.1523/JNEUROSCI.4419-03.2004

Copyright $\odot 2004$ Society for Neuroscience $\quad$ 0270-6474/04/243199-11\$15.00/0
}

The M-cell is known to play an important role in escape behaviors from predators. During escape, an abrupt stimulus to the fish leads to a fast C-shaped body bend toward the opposite side [C-start (Eaton et al., 1981)]. There is a tight link between M-cell firing and the initiation of the C-start (Zottoli, 1977; Eaton et al., 1982, 1988; Hackett and Greenfield, 1986; Oda et al., 1998). $\mathrm{M}$-cells receive excitatory inputs from the auditory [posterior (p)] and vestibular (anterior) branches of the eighth nerve (pVIIIn), the posterior lateral line nerve, and the optic tectum (Faber et al., 1991). The pVIIIn afferent inputs directly excite the M-cell through mixed electrical and chemical synapses (Furshpan, 1964; Nakajima, 1974; Tuttle et al., 1986; Lin and Faber, 1988). The M-cell axon synapses on the contralateral spinal motoneurons innervating the trunk muscles (Fetcho and Faber, 1988). Thus, the principal circuit for producing fast escape is composed of pVIIIn, an M-cell, and contralateral spinal motoneurons. However, activation of the M-cell produces only the initial phase of the C-start (Nissanov et al., 1990), suggesting involvement of other RS neurons in the control of the subsequent body movement (Foreman and Eaton, 1993). Calcium imaging analysis in larval zebrafish shows that the M-cell homologs are activated by head-tap stimuli, presumably through activation of the auditory system (O'Malley et al., 1996). However, very little is known about the sensory inputs and electrophysiological properties of $\mathrm{MiD} 2 \mathrm{~cm}$ or $\mathrm{MiD} 3 \mathrm{~cm}$.

To understand how the M-series neurons sense auditory in- 
puts and transform them into output firing, we examined the pVIIIn afferent projection, synaptic responses evoked by auditory stimulation, and the firing patterns of these neurons in adult goldfish. Here, we demonstrate morphologically that the pVIIIn afferents project to $\mathrm{r} 4-\mathrm{r} 6$. All $\mathrm{M}$-series neurons receive excitatory inputs from the pVIIIn afferents but exhibit different firing properties. While the M-cell shows single spiking mediated by both dendrotoxin-I (DTX-I)-sensitive potassium channels and the recurrent inhibition, $\mathrm{MiD} 2 \mathrm{~cm}$ and $\mathrm{MiD} 3 \mathrm{~cm}$ show repetitive firing in response to stepwise depolarization. These data suggest that all three M-series neurons participate in sound-induced escape behavior by carrying different aspects of the inputs to the spinal cord.

\section{Materials and Methods}

Intracellular recordings. Electrophysiological experiments were performed on adult goldfish (Carassius auratus, 7-9 cm in standard length) in air at $20^{\circ} \mathrm{C}$. All procedures were performed in compliance with the guidelines stipulated by the Osaka University Committee on Animal Research. Fish were anesthetized with $0.015 \% 3$-aminobenzoic acid ethyl ester (MS222; Sigma, St. Louis, MO), immobilized with D-tubocurarine chloride ( $2 \mu \mathrm{g} / \mathrm{gm}$ body weight; Sigma), and held horizontally in a recording chamber with tapered rods at the head and body, as shown previously (Furshpan and Furukawa, 1962). During the experiment, fish were artificially respirated by gill perfusion with aerated water containing anesthetic (0.007\% MS222). The skull was opened, and the cerebellum was retracted rostrally to expose the medullar surface. Experimental set-up is illustrated in Figure $1 \mathrm{~B}$. Thin bipolar tungsten electrodes, insulated except at the very tips and separated by $\sim 100 \mu \mathrm{m}$, were placed on the pVIIIn. Silver bipolar electrodes were placed just above the vertebral column for antidromic (AD) activation of the axons of RS neurons. Sound stimuli were applied from a loudspeaker positioned $60 \mathrm{~cm}$ to the left of the fish. Intracellular recordings were obtained from the $\mathrm{M}$-series neurons with an Axoprobe-1A dual-channel preamplifier (Axon Instruments, Foster City, CA). Recording micropipettes were filled with $4 \mathrm{M}$ potassium acetate $(7-15 \mathrm{M} \Omega$ at $60 \mathrm{~Hz})$ containing 3-5\% neurobiotin (Vector Laboratories, Burlingame, CA). We first located the M-cell axon cap, a glial structure surrounding the axon hillock, with the help of the antidromically evoked large negative field potential (see Fig. $4 \mathrm{~A}$, bottom) (Furshpan and Furukawa, 1962). The locus of the maximum field potential of M-cell spikes $(>30 \mathrm{mV})$ in the axon cap was used as a landmark for finding the RS neurons in $\mathrm{r} 5$ and r6. RS neurons were located with the help of field potentials of AD spikes evoked by spinal cord stimulation. All of the recorded RS neurons were labeled with neurobiotin and reconstructed by camera lucida drawings for morphological identification. In this study, $\sim 90 \%$ of the recorded neurons were successfully labeled with neurobiotin iontophoretically injected through the recoding micropipette. Four types of RS neurons (MiD-cm, MiD-cl, MiD-i, and MiV) were identified in r5 and r6, as shown previously (Metcalfe et al., 1986; Lee et al., 1993a). Among them, the RS neurons with axons that crossed the midline and descended along with the M-cell axon in the medial longitudinal fasciculus (mlf) toward the contralateral spinal cord were identified as $\mathrm{MiD} 2 \mathrm{~cm}$ or $\mathrm{MiD} 3 \mathrm{~cm}$. Electrophysiological data from morphologically identified $\mathrm{MiD} 2 \mathrm{~cm}$ and $\mathrm{MiD} 3 \mathrm{~cm}$ were analyzed. To assess membrane excitability, stepwise depolarizing currents were injected through the recording micropipettes, and the firing responses were observed. For the M-cell, $\theta$-style microelectrodes (TGC200-10; Harvard Apparatus, Edenbridge, UK) were used, because very large currents were needed to fire the M-cell because of its low input resistance [70-200 $\mathrm{k} \Omega$ (Faber and Korn, 1978)], with one channel for passing current and the other for recording the voltage responses. Firing patterns of M-cells but not fast voltage responses within an action potential were compared under several conditions, because the latter might be affected by compensation of the coupling capacitance between the two channels of the $\theta$-style micropipette. Blockers of receptors and channels were obtained from Sigma, except 6,7-dinitroquinoxaline-2,3-dione (DNQX) and D-(-)-2-amino-5-phosphonopentanoic acid (D-APV), which were ob- tained from Tocris Cookson (Bristol, UK). Electrophysiological data from RS neurons with resting membrane potentials $\left(E_{\text {rest }}\right)$ ranging from -70 to $-85 \mathrm{mV}$ were analyzed. Data represent means \pm SEM (number of cells). The Mann-Whitney $U$ test was used to assess statistical significance.

Intracellular labeling of RS neurons. Recorded neurons were identified morphologically. We injected neurobiotin from the micropipette by passing iontophoretic anodal current pulses (10-20 nA) of $700 \mathrm{msec}$ duration every $2 \mathrm{sec}$ for $15 \mathrm{~min}$. Action potentials and membrane potentials were monitored during the tracer injection. After a survival time of $1-3 \mathrm{hr}$, the fish were perfused transcardially with $0.9 \%$ saline followed by a solution of $4 \%$ paraformaldehyde (PFA) in PBS, pH 7.4. Their brains were removed from the skulls, postfixed overnight at $4^{\circ} \mathrm{C}$, and then immersed overnight at $4^{\circ} \mathrm{C}$ in PBS containing $20 \%$ sucrose for cryoprotection. The brains were embedded in $5 \%$ agarose (type IX; Sigma) containing $20 \%$ sucrose in PBS and quickly frozen with $-50^{\circ} \mathrm{C} n$-hexane. Serial coronal or horizontal sections were cut at $50 \mu \mathrm{m}$ on a cryostat (CM1850; Leica, Nussloch, Germany). Sections were mounted on gelatin-coated slides, dried for $1 \mathrm{hr}$, and then treated with a $0.3 \% \mathrm{H}_{2} \mathrm{O}_{2}$ solution in methanol for $15 \mathrm{~min}$ to block endogenous peroxidase activity. After washing thoroughly, the sections were incubated with $\mathrm{ABC}$ solution (ABC elite kit, 1:100; Vector Laboratories) for $3 \mathrm{hr}$ at room temperature. The sections were rinsed and reacted with a $0.05 \% 3^{\prime}, 3^{\prime}$ diaminobenzidine (DAB; Dojin, Kumamoto, Japan) solution containing $0.01 \% \mathrm{H}_{2} \mathrm{O}_{2}$ and $0.04 \%$ nickel ammonium sulfate. The sections were then dehydrated through ethanol series, cleaned in xylene, and coverslipped. The labeled neurons were photographed with a digital CCD camera (Axiocam HRc; Zeiss, Oberkochen, Germany), mounted on a light microscope (Axioskop; Zeiss), and reconstructed by camera lucida.

Retrograde labeling of RS neurons. Hindbrain RS neurons were retrogradely labeled to investigate their rostrocaudal arrangement in adult goldfish, as shown previously in juvenile goldfish (Lee et al., 1993a). Fish were anesthetized with MS222 and mounted on the chamber as mentioned above. The spinal cord was exposed at the cervical level, and a minimal crystal of biocytin (Sigma) was inserted into the spinal cord using a fine needle. After injection, the dorsal opening was sealed with a waterproof sheet. After a survival period of $3 \mathrm{~d}$ in a tank, the fish were fixed by transcardial perfusion. The subsequent sectioning, reaction, and staining procedures were the same as those used for intracellular labeling of RS neurons.

Afferent projection from pVIIIn to RS neurons. To examine the morphology of the projection of pVIIIn afferents to hindbrain RS neurons, we labeled the pVIIIn afferents and RS neurons with different fluorescent tracers. To label the RS neurons retrogradely, Oregon Green 488conjugated dextran (molecular weight of 10,000; Molecular Probes, Eugene, OR), dissolved in a very small quantity of distilled water and then recrystallized, was injected into the spinal cord at the cervical level. Fish were maintained postoperatively in a dark tank for $3 \mathrm{~d}$. Fish were then deeply anesthetized by $0.05 \%$ MS 222 solution, perfused intracardially with chilled saline followed by chilled $4 \%$ PFA solution, and postfixed in the same fresh fixative at $4^{\circ} \mathrm{C}$ for $24 \mathrm{hr}$. Cranial nerves were removed, and the brain was circumfused with $5 \%$ gelatin (type A; Sigma) to prevent neuronal tracers from scattering. To label the pVIIIn afferents, a small crystal of 1,1-dilinoleyl-3,3,3',3'-tetramethylindocarbocyanine (DiI; Molecular Probes) was inserted unilaterally into the peripheral part of both the saccular and lagenar nerves. The insertion site was covered with $5 \%$ gelatin, and the brains were stored in fresh fixative in darkness at $37^{\circ} \mathrm{C}$ for 2 weeks. The brains were embedded in $7 \%$ gelatin, fixed for $3 \mathrm{~d}$, and sectioned horizontally with a Vibratome (VT1000S; Leica) at $80 \mu \mathrm{m}$. The serial sections were mounted on slides, observed with an epifluorescence microscope (Axioskop; Zeiss), and photographed with a digital CCD camera.

Immunohistochemistry for Kv1.2 $\alpha$-subunit. Fish were perfused transcardially with chilled $0.9 \%$ saline followed by a $4 \%$ PFA solution. Serial cryostat sections $(50 \mu \mathrm{m})$ were cut and mounted on gelatin-coated slides. The sections were blocked by incubating them in PBS containing 3\% normal goat serum (NGS; Vector Laboratories) and 0.03\% Triton X-100 for $1 \mathrm{hr}$. Next, polyclonal anti-rat Kv1.2 antibodies raised from rabbits (1:100; Alomone Labs, Jerusalem, Israel) were applied overnight at room 
temperature at a dilution of $1: 100$ containing $2 \%$ NGS and $0.03 \%$ Triton $\mathrm{X}-100$. The sections were then incubated with a biotin-labeled secondary antibody (goat anti-rabbit, 1:200; Vector Laboratories) for $3 \mathrm{hr}$. After that, the sections were incubated in $\mathrm{ABC}$ solution and reacted with nickel-DAB solution. The secondary antibody was diluted in a solution containing 2\% normal fish serum (Seablock; Pierce, Rockford, IL) to prevent background signal from nonspecific binding of the secondary antibody. Control sections were prepared both by omitting the primary antibodies and by preabsorbing the antibodies with the fusion proteins that were used as the antigen (Alomone Labs) at room temperature for 2 hr. A monoclonal anti-rat Kv1.2 antibody, raised from mice (1:100; Upstate Biotechnology, Lake Placid, NY), was also tested.

\section{Results}

\section{Segmental arrangement of RS neurons in adult goldfish}

Retrograde labeling of RS neurons from the spinal cord of an adult goldfish showed that the RS neurons were clustered in seven discrete groups along the hindbrain neuraxis (Fig. 1A1), as described previously in juveniles (Lee et al., 1993a). By convention, these clusters are designated r1-r7 from rostral to caudal. The clusters appeared periodically with a spacing of $\sim 400 \mu \mathrm{m}$ for $\mathrm{r} 1-\mathrm{r} 5$ and $\sim 600 \mu \mathrm{m}$ for $\mathrm{r} 5-\mathrm{r} 7$. Thus, the segmental organization of the hindbrain RS neurons in goldfish is maintained in the adult, as demonstrated in zebrafish (Kimmel et al., 1982; Metcalfe et al., 1986; Lee and Eaton, 1991). The M-cell and its segmentally homologous neurons, $\mathrm{MiD} 2 \mathrm{~cm}$ and $\mathrm{MiD} 3 \mathrm{~cm}$, are bilaterally located in the middle segments, $\mathrm{r} 4-\mathrm{r} 6$, respectively (Fig. 1A2).

\section{Morphological characteristics of the Mauthner series}

The morphology of each of the M-series neurons was examined by camera lucida reconstruction from serial sections containing intracellularly labeled neurons. Images of horizontal sections that contain $\mathrm{M}$-series neurons in a fish are shown in Figure 2, and the camera lucida reconstruction is shown in Figure $3 A$. The reconstruction of coronal sections containing $\mathrm{M}$-series neurons in different fish is shown in Figure $3 B-D$. The distinguishing features of the M-cell were the large size of the soma (Fig. 2A2, asterisks) and two thick principal dendrites, namely the lateral and ventral dendrites (Figs. $2 A 1-A 4,3 A, B$, filled and open arrowheads, respectively). The Mauthner axon (M-axon) decussated and descended in the dorsal part of the mlf $\left(\mathrm{mlf}_{\mathrm{D}}\right)$ toward the spinal cord (Fig. 2A1,A2, thick arrows). The soma of MiD2cm (Fig. $2 \mathrm{~B} 3$, asterisk), like the $\mathrm{M}$-cell, was located in the dorsal cluster of hindbrain RS neurons, $\sim 350 \mu \mathrm{m}$ caudal to the $\mathrm{M}$-cell axon cap (Fig. 3A, Table 1). The axon of MiD2 $\mathrm{cm}$ crossed the midline and descended in the contralateral $\mathrm{mlf}_{\mathrm{D}}$, along with the $\mathrm{M}$-axon in the medulla oblongata (Figs. $2 \mathrm{B1}$, open arrows, $3 A$ ). The $\mathrm{MiD} 2 \mathrm{~cm}$ had two principal dendrites. One extended caudolaterally and slightly dorsally, and the other extended rostroventrally (Figs. $2 B 2-B 4,3 A, C$, filled and open arrowheads, respectively). Both dendrites branched into higher-ordered thin branches and covered larger fields than those of the M-cell. In 7 of 16 cells examined, we observed a third type of dendrite. It extended ventromedially, and in three cases, it partially crossed the midline into the contralateral side (Fig. 3A,C, gray arrowheads). The soma of MiD3cm (Fig. 2C2, asterisk) was also located in the dorsal clusters, $\sim 650 \mu \mathrm{m}$ caudal to MiD2cm (Fig. 3A, Table 1). The axon of the $\mathrm{MiD} 3 \mathrm{~cm}$ decussated in the hindbrain (Fig. 2C1, gray arrow) and descended along with the $\mathrm{M}$-axon in the $\mathrm{mlf}_{\mathrm{D}}$ into the contralateral spinal cord (Fig. $3 A$ ). Typically, $\mathrm{MiD} 3 \mathrm{~cm}$ also had two principal dendrites, one projecting dorsolaterally and the other projecting rostroventrally (Figs. $2 C 1, C 3, C 4,3 A, D$, filled and open arrowheads, respectively). Although there are differences in their higher-order and widely spread dendritic arborizations,
MiD2 $\mathrm{cm}$ and $\mathrm{MiD} 3 \mathrm{~cm}$ share the morphological motif of the $\mathrm{M}$ cell: dorsally located soma, a contralaterally projecting axon descending in the mlf $_{\mathrm{D}}$, and principal lateral and ventral dendrites.

\section{Antidromic responses of the M-series neurons}

Electrical stimulation of the spinal cord elicited an $\mathrm{AD}$ action potential in the $\mathrm{M}$-cell soma in an all-or-none manner at the threshold intensity (Fig. $4 \mathrm{~A}$ ). The onset latency ranged from 0.20 to $0.42 \mathrm{msec}$, with an average of $0.26 \pm 0.01 \mathrm{msec}$ ( 30 cells) (Fig. $4 C)$. The amplitude of $\mathrm{AD}$ spikes measured from baseline in the $\mathrm{M}$-cell soma was always $<50 \mathrm{mV}$ (Fig. $4 A$, top). This is attributable to a large voltage drop extracellularly within the axon cap (Fig. $4 A$, bottom) and the electrical inexcitability of the somadendritic membrane of the M-cell (Furshpan and Furukawa, 1962). In MiD2cm, the onset latency of $\mathrm{AD}$ spikes ranged from 0.42 to $0.92 \mathrm{msec}$, with an average of $0.58 \pm 0.03 \mathrm{msec}$ (17 cells) (Fig. $4 B, C$ ), and in $\mathrm{MiD} 3 \mathrm{~cm}$, the onset latency of $\mathrm{AD}$ spikes ranged from 0.40 to $0.90 \mathrm{msec}$, with an average of $0.57 \pm 0.03$ msec (17 cells) (Fig. 4C). The latencies of MiD2 $\mathrm{cm}$ or MiD $3 \mathrm{~cm}$ were significantly longer than that of the M-cell $(p<0.001)$, indicating slower conduction velocity of their thinner axons $(\sim 15 \mathrm{vs} \sim 50 \mu \mathrm{m})$ (Fig. 3). The spike amplitudes from baseline of $\mathrm{MiD} 2 \mathrm{~cm}$ and $\mathrm{MiD} 3 \mathrm{~cm}$ appeared larger than that of the $\mathrm{M}$-cell (Fig. 4A,B, top). This could be explained by the fact that we did not observe a large extracellular field potential near $\mathrm{MiD} 2 \mathrm{~cm}$ or MiD3cm (Fig. 4B, bottom), suggesting that neither MiD2 $\mathrm{cm}$ nor $\mathrm{MiD} 3 \mathrm{~cm}$ has an axon cap-like structure.

\section{Inputs from pVIIIn afferents to RS neurons}

One of the dominant excitatory inputs to the M-cell that triggers the fast escape comes from the pVIIIn afferents. It has been established morphologically as well as electrophysiologically that the pVIIIn afferents make mixed electrical and chemical synapses on the distal lateral dendrite of the ipsilateral M-cell (Furshpan, 1964; Nakajima, 1974; Faber and Korn, 1978; Tuttle et al., 1986; Lin and Faber; 1988; Faber et al., 1991). Projection areas of the pVIIIn afferents within the brain have been described previously in goldfish (McCormick and Braford, 1994). However, it was not known whether the afferents connect to RS neurons other than M-cells. In the present study, we first examined this issue anatomically by labeling the pVIIIn afferents and the RS neurons with DiI and Oregon Green 488, respectively. Projections from the DiI-labeled pVIIIn afferents to the first-order octaval nuclei were observed as described previously (McCormick and Braford, 1994). Interestingly, the pVIIIn afferents formed four discrete bundles and extended medially to the vicinity where the lateral dendrites of dorsally located RS neurons, including the M-series neurons, are probably located (nine fish) (Fig. 5A, compare Fig. $3)$. The most rostral bundle appeared to contact the distal part of the M-cell lateral dendrite (Fig. 5A,B), as shown previously (Lin et al., 1983; Pereda et al., 1995). The second rostral and the fourth bundles of pVIIIn appeared to project to $\mathrm{r} 5$ and $\mathrm{r} 6$, respectively (Fig. 5A,C). The pVIIIn afferents did not enter more ventral regions where ventral RS neurons (MiV cells) were located. These results suggest that the projections of pVIIIn afferents are segmentally organized and target the dorsally located RS neurons in r4-r6.

Next, we assessed electrophysiologically whether pVIIIn forms synapses onto $\mathrm{MiD} 2 \mathrm{~cm}$ and $\mathrm{MiD} 3 \mathrm{~cm}$ as it does for the M-cell. Electrical stimulation of pVIIIn evoked initial fast EPSPs, followed by slow EPSPs in the M-cell (Fig. 6A, open and filled arrowheads, respectively) with a short latency $(0.19 \pm 0.00 \mathrm{msec}$; 16 cells) (Fig. $6 A$ ). It has been demonstrated that those fast and 


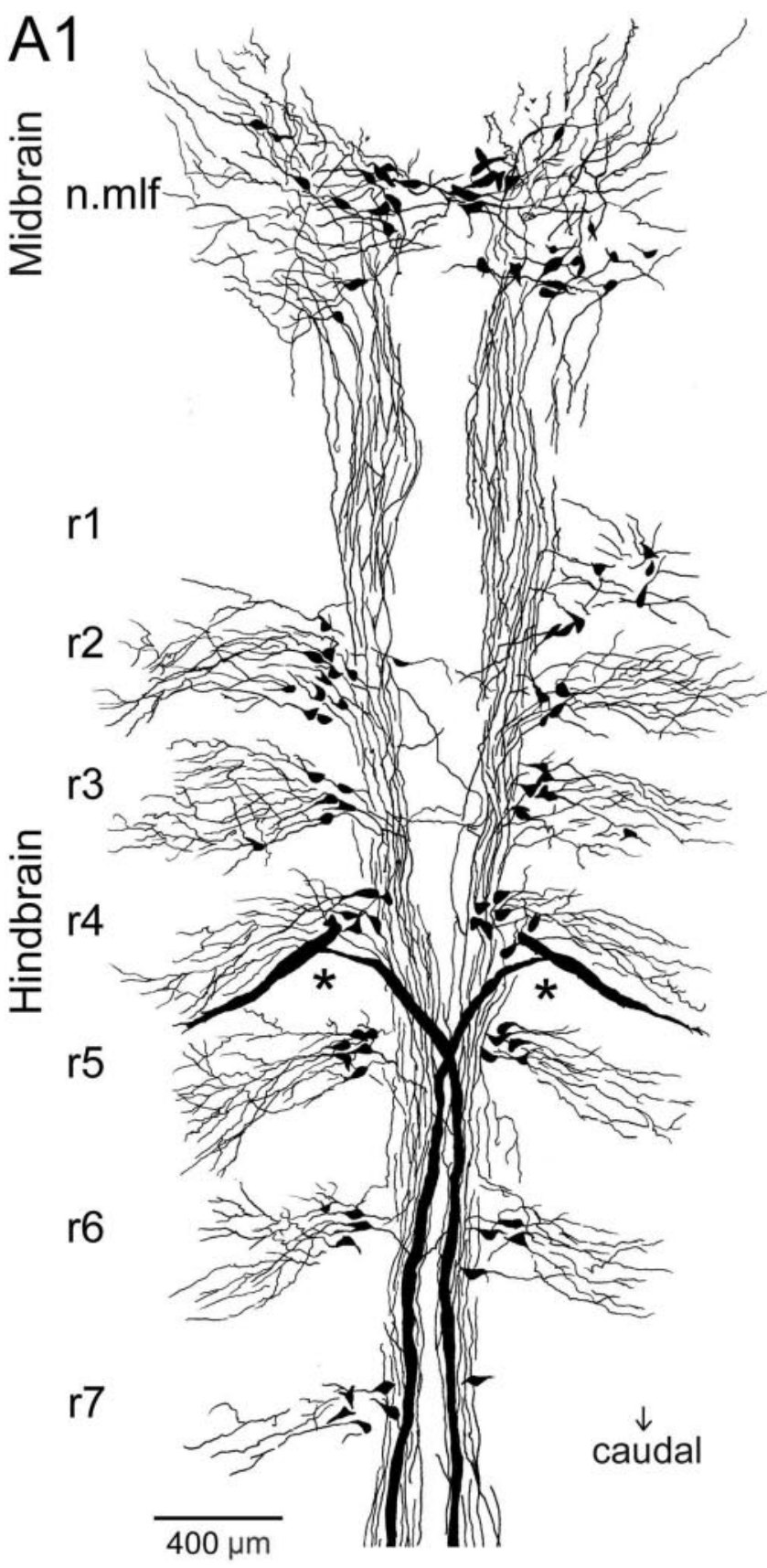

slow EPSPs are mediated by electrical and chemical synapses, respectively (Furshpan, 1964; Faber and Korn, 1978; Lin and Faber; 1988; Faber et al., 1991). Similar biphasic, fast, and slow EPSPs with constant onset latencies were observed in $\mathrm{MiD} 2 \mathrm{~cm}$ in response to pVIIIn stimulation (Fig. $6 B)$. The latency $(0.46 \pm$ 0.03 msec; nine cells) was longer than that of the M-cell ( $p<$ 0.001). Stimulation of pVIIIn at intensities that were subthreshold to fire the M-cell evoked action potentials in seven of nine MiD2 $\mathrm{cm}$ cells in the same fish (data not shown). Stimulation of pVIIIn also evoked EPSPs in MiD3cm (Fig. 6C) with an onset latency of $0.67 \pm 0.03 \mathrm{msec}$ (nine cells), also longer than that of the M-cell $(p<0.001)$. The EPSPs elicited in MiD3cm consisted of a fast potential (Fig. $6 C$, open arrowhead) with little onset fluctuation and subsequent fast but fluctuating potentials (Fig. $6 \mathrm{C}$, asterisks). Most MiD3 $\mathrm{cm}$ cells had a higher firing threshold in response to pVIIIn stimulation than that of the M-cell (eight of nine cells).

Furthermore, we explored whether natural auditory stimulation could evoke synaptic responses in $\mathrm{M}$-series neurons. Tone bursts of $500 \mathrm{~Hz}$ with intensities of $95-100 \mathrm{~dB}$ were applied. The $\mathrm{M}$-series neurons showed EPSPs in response to the tone bursts. Sharp depolarizing potentials in response to both condensation and rarefaction phases of sound were evoked in M-cells (Fig. 6D). The response started $0.94 \pm 0.02 \mathrm{msec}$ ( 21 cells) after the onset of sound. The sharp potentials seem to be the coupling potentials through the electrical synapses, associated with activities of presynaptic pVIIIn afferents synchronized to the sound (Fay, 1995). The sound consists of two components, particle motion and pressure change. The failure in firing $\mathrm{M}$-cells might be attributable to reduction of the relative movement of otic particles in fish sustained in the air compared with that of freely swimming fish in the water (Canfield and Eaton, 1990; Casagrand et al., 1999). $\mathrm{MiD} 2 \mathrm{~cm}$ cells generated action potentials in response to the same stimuli (11 of 12 cells) (Fig. 6E1). Sharp EPSPs similar to those in the M-cell were observed when the cell was hyperpolarized (Fig. $6 E 2)$. The onset latency of MiD2 $\mathrm{cm}$ was $1.20 \pm 0.03 \mathrm{msec}(12$ cells), slightly longer than that of the M-cell $(p<0.01)$. Sound stimulation also evoked EPSPs in the MiD3cm (Fig. 6F). However, the onset in $\mathrm{MiD} 3 \mathrm{~cm}(1.46 \pm 0.09 \mathrm{msec}, 10$ cells) was the most delayed among the members of the $\mathrm{M}$-series neurons. These data show that $\mathrm{MiD} 2 \mathrm{~cm}$ and $\mathrm{MiD} 3 \mathrm{~cm}$, like the $\mathrm{M}$-cell, are excited by auditory inputs. However, their latencies are longer, and their firing thresholds are different.

$\leftarrow$

Figure 1. A, Segmental arrangement of hindbrain $\mathrm{RS}$ neurons in an adult goldfish. A1, RS neurons labeled retrogradely with biocytin were reconstructed from 15 serial horizontal sections, each $50 \mu \mathrm{m}$ in thickness. RS neurons were divided into seven clusters along the neuraxis, $r 1-r 7$, rostral to caudal. The largest RS neurons, M-cells, were bilaterally located in r4 (asterisks). Neurons in the nucleus of $\mathrm{mlf}$ (n.mlf) are located in the midbrain. The difference in labeled RS neurons between the right and the left side is a result of incomplete transport of biocytin from the injection site. $A 2$, Schematic representation of the M-series neurons: $M-c e l l, M i D 2 c m$, and $M i D 3 \mathrm{~cm}$. Somata of the paired M-series neurons are bilaterally located dorsally in $\mathrm{r} 4-\mathrm{r} 6$ (the first to third of middle segments of hindbrain), respectively, and their axons descend into the contralateral spinal cord via the $\mathrm{mlf}_{\mathrm{D}}$ after decussating in the hindbrain. The dashed line indicates the midline. $B$, The schematic diagram indicates the experimental set-up. Intracellular recordings were performed from M-series neurons with glass micropipettes filled with $4 \mathrm{M}$ potassium acetate containing neurobiotin to label the recorded neurons. Bipolar stimulating electrodes were placed on the vertebral column for antidromic activation of the RS axons and on the pVIIIn for orthodromic activation of the synaptic inputs. Sound stimulation was applied from a loudspeaker positioned on the left side of the fish. 

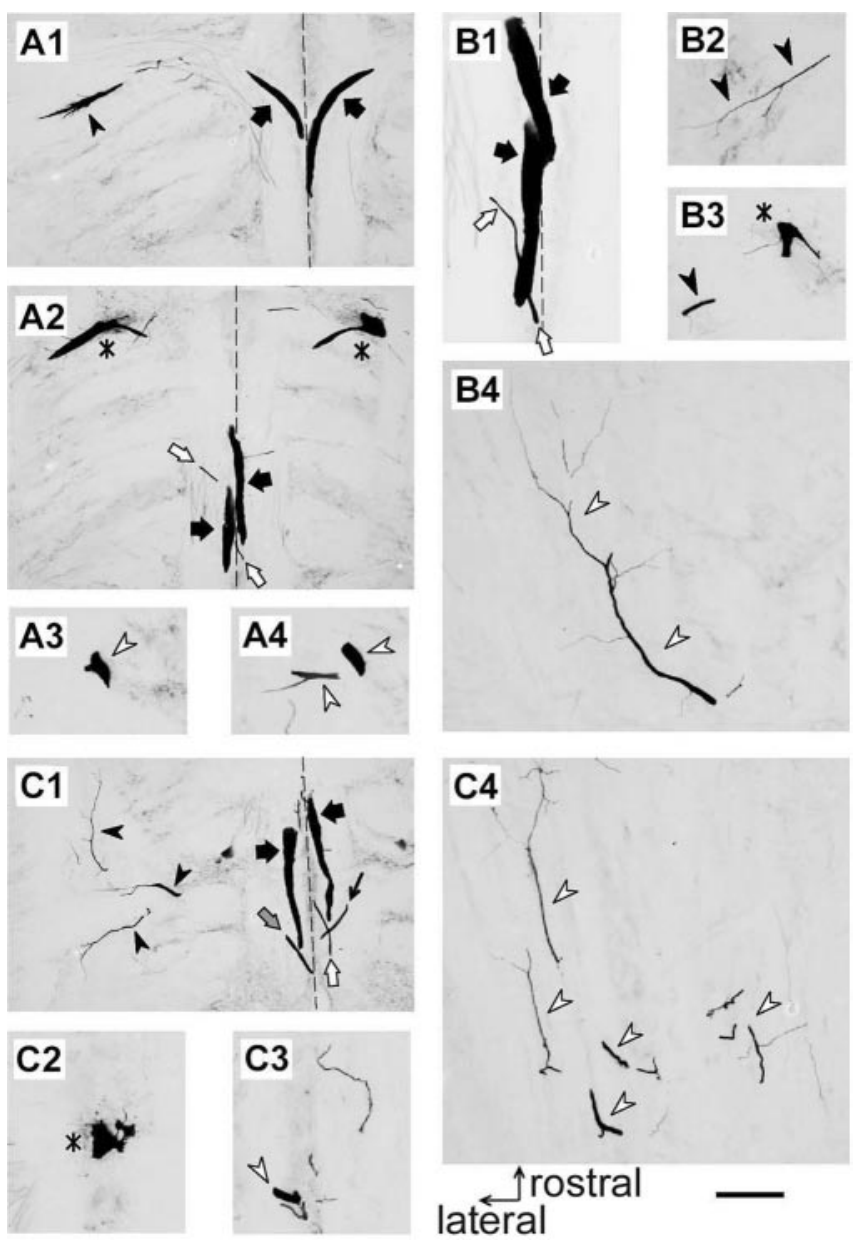

Figure 2. Intracellularly labeled M-series neurons. Horizontal sections include bilateral $M$-cells, left MiD2cm, and left MiD3cm from one fish. $A 1-A 4$ depict dorsal to ventral sections, as do $B$ and C. A1, Distal lateral dendrite (filled arrowhead) of the left M-cell and thick crossing axons of bilateral M-cells (filled arrows) were labeled. A2, Somata (asterisks) and descending axons (filled arrows) of bilateral M-cells and thin axon of left MiD2cm (open arrows). A3, A4, Horizontal sections of $\mathrm{M}$-cell ventral dendrite extending rostroventrally (open arrowheads). $B 1$, Axons of bilateral M-cells (filled arrows) and crossing axon of the left MiD2cm (open arrows). $B 2-B 4$, Lateral dendrite ( $B 2, B 3$, filled arrowheads), soma ( $B 3$, asterisk), and ventral dendrites with small branches ( $B 4$, open arrowheads) of the left MiD2cm were labeled. $C 1$, Lateral dendrites (filled arrowheads) and crossing axon (gray arrow) of the left MiD3cm were clearly labeled. Filled and open arrows indicate axons of the bilateral $\mathrm{M}$-cell and the left $\mathrm{MiD} 2 \mathrm{~cm}$, respectively. Another fiber (thin arrow) was an axon of right MiD3cm. C2-C4, Soma (C2, asterisk), proximal ( $(3$, open arrowhead), and distal ventral dendrites ( $C 4$, open arrowheads) of the left $M i D 3 \mathrm{~cm}$. Dashed lines indicate the midline. Calibration: $A 1, A 2, C 1,200 \mu \mathrm{m} ; A 3, A 4, B 1-B 4$, $C 2-C 4,100 \mu \mathrm{m}$. These labeled neurons were reconstructed by camera lucida drawing, as shown in Figure $3 A$.

\section{Firing properties of the $\mathbf{M}$-series neurons}

Although the $\mathrm{M}$-series neurons all received auditory inputs, they showed different firing properties in response to stepwise membrane depolarization. A much larger current (105.8 $\pm 7.09 \mathrm{nA} ; 17$ cells) was needed to fire the $M$-cell than $M i D 2 \mathrm{~cm}$ and $M i D 3 \mathrm{~cm}$ (MiD2cm, $5.1 \pm 0.98 \mathrm{nA}, 10$ cells; MiD3cm, $12.7 \pm 3.34 \mathrm{nA}, 6$ cells). The $\mathrm{M}$-cell produced only a single action potential with a stepwise depolarizing current of up to 1.5 times threshold (1.5T). The action potential of the M-cell was followed by recurrent IPSPs (Fig. 7A, asterisk), which are mediated mainly by glycinergic interneurons and in part by GABAergic interneurons in the collateral network of the M-cell (Furukawa et al., 1964; Diamond and Huxley, 1968; Triller and Korn, 1981; Lee et al., 1993b). When much larger currents (2T) (Fig. 7A) were applied, an ad-

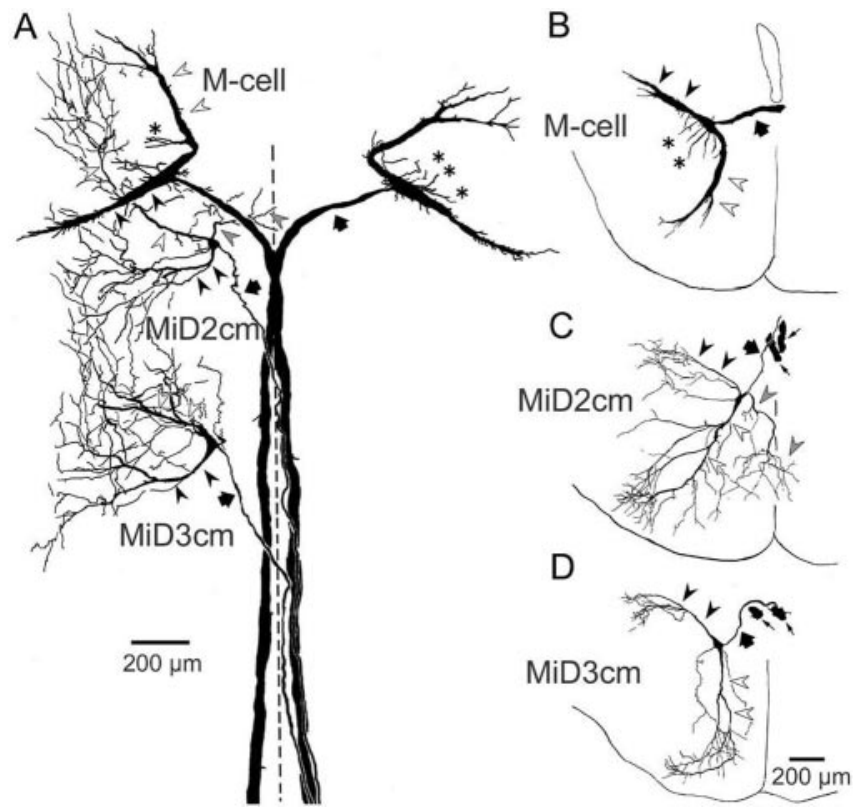

Figure 3. Camera lucida reconstruction of the M-series from serial horizontal $(A)$ and coronal $(B-D)$ sections. $A$, Intracellularly labeled bilateral $M$-cells, left $M i D 2 \mathrm{~cm}$, and left $M i D 3 \mathrm{~cm}$ in a fish, which were shown in Figure 2 . The axons, lateral dendrites, and ventral dendrites are indicated by thick arrows, filled arrowheads, and open arrowheads, respectively. $B-D$, Coronal views of the M-series neurons in different fish. Axons of the M-series neurons (thick arrows) crossed the midline and descended along the contralateral $\mathrm{mlf}_{\mathrm{D}}$. Lateral dendrites (filled arrowheads) of the M-series neurons extended caudolaterally, and ventral dendrites (open arrowheads) extended rostroventrally. The M-cell had additional small dendrites extending from the soma (asterisks; also in A). The MiD2cm had a medial dendrite extending ventromedially, the peripheral part of which entered into the contralateral brain (gray arrowheads; also in $A$ ). The thin arrows in ( and $D$ indicate axons of bilateral M-cells. The calibration in $D$ is also applied to $B$ and $C$. $A-D$ are a composite respectively of 24 , 6,7 , and 15 serial sections, each $50 \mu \mathrm{m}$ in thickness. The dashed line indicates the midline. Up is rostral in $A$ and dorsal in $B-D$.

Table 1. Location of the somata of MiD2 $\mathrm{cm}$ and MiD3 $\mathrm{cm}$ (micrometers from M-cell axon cap)

\begin{tabular}{lll}
\hline & $\operatorname{MiD} 2 \mathrm{~cm}(n=17)$ & $\operatorname{MiD3cm}(n=17)$ \\
\hline Caudal & $359 \pm 11.5$ & $991 \pm 16.2$ \\
Medial & $183 \pm 12.1$ & $175 \pm 12.5$ \\
Ventral & $124 \pm 31.3$ & $143 \pm 31.1$ \\
\hline
\end{tabular}

Values represent distances from the axon cap of the M-cell to intracellularly recorded MiD2 $2 \mathrm{~cm}$ and $M i D 3 \mathrm{~cm}$ along three-dimensional axes (means $\pm \mathrm{SEM} ; n=$ number of cells).

ditional spike was elicited after the recurrent IPSPs, probably as a result of postinhibitory rebound excitation. The lack of IPSPs after the second spike may be explained by the frequencydependent depression of the collateral inhibitory network (Furukawa and Furshpan, 1963; Waldeck et al., 2000) or failure of synaptic transmission caused by the small amplitude of the second spike. In contrast to the M-cell, $\mathrm{MiD} 2 \mathrm{~cm}$ and $\mathrm{MiD} 3 \mathrm{~cm}$ exhibited tonic, repetitive firing at constant frequencies almost proportional to the amplitude of the injected current (Fig. 7B1,B2). The average rate of rise in frequency was $26.2 \pm 3.03 \mathrm{~Hz} / \mathrm{nA}(10$ cells) in MiD2 cm and $28.5 \pm 5.33 \mathrm{~Hz} / \mathrm{nA}$ (six cells) in MiD3cm. Neither MiD2 cm nor MiD $3 \mathrm{~cm}$ seemed to receive recurrent inhibition, because no IPSPs were recorded after the spikes in these experiments, and depolarizing IPSPs were not observed when high $\mathrm{Cl}^{-}$was loaded intracellularly from the recording micropipette (data not shown). Together, the M-series neurons possess distinct firing properties; only the M-cell showed a propensity for generating single spikes among the M-series neurons. 
A
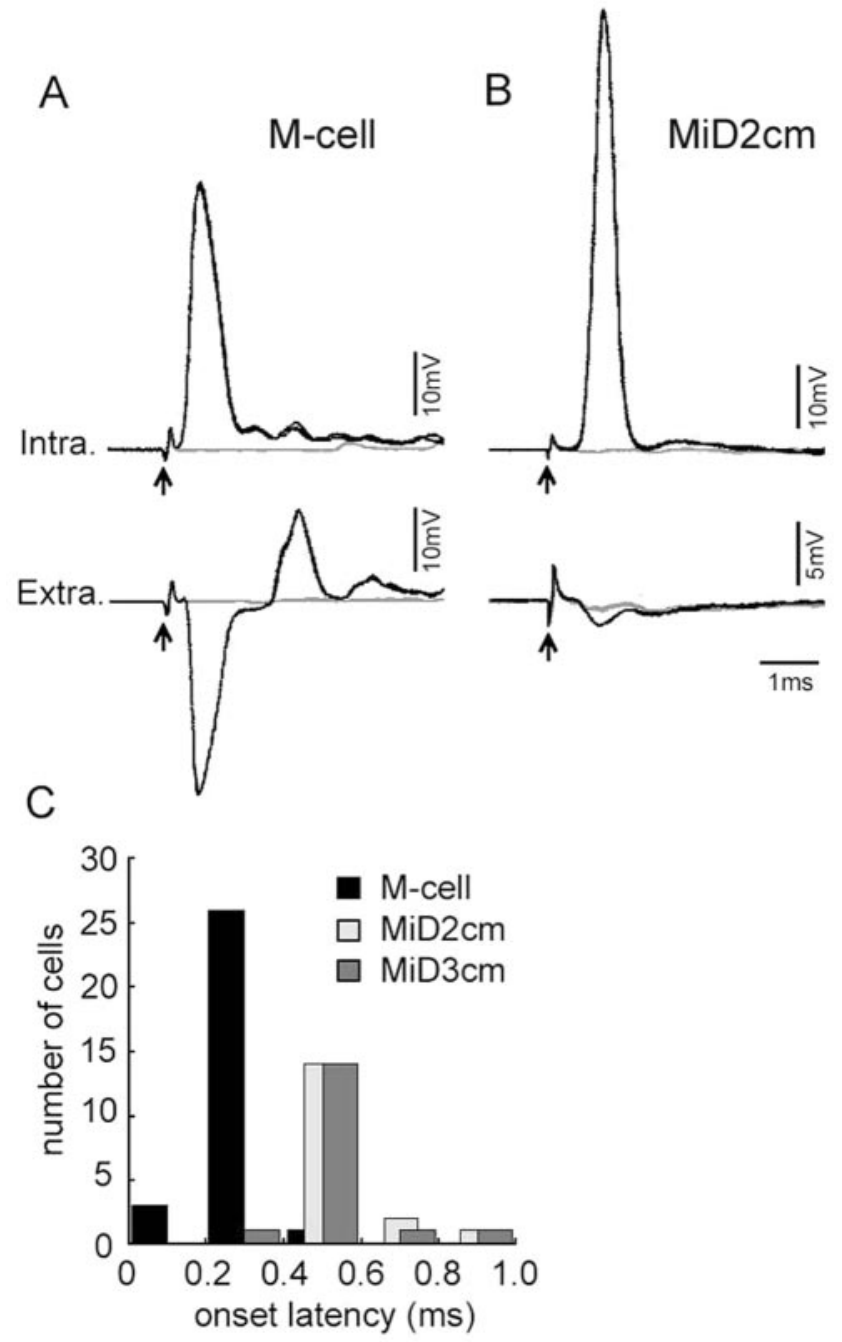

Figure 4. Antidromically evoked action potentials of $M$-series neurons. $A, B, A D$ spikes recorded intracellularly (Intra.) in an M-cell and a MiD2cm, respectively, in response to spinal cord stimulation at threshold intensities (top traces). Corresponding extracellular (Extra.) field potentials are shown below. Failures were represented by gray traces. Three responses were overlaid for each. The onset latency of AD spikes was $0.26 \mathrm{msec}(A)$ and $0.46 \mathrm{msec}(B)$, respectively. $E_{\text {rest }}$ was $-76 \mathrm{mV}$ in the M-cell and $-77 \mathrm{mV}$ in the MiD2 $\mathrm{cm}$. Note that the large negative field potentials were observed in the axon cap of the M-cell ( $A$, bottom). C, Frequency histogram of onset latencies of AD spikes from spinal stimulation. The latencies of M-cells (30 cells) were shorter than those of MiD2cm (17 cells) and MiD3cm (17 cells).

\section{Mechanisms for the transient firing property of the M-cell}

The differences in the firing patterns of the M-cell and its homologs indicate heterogeneity in the composition of their voltage-gated channels or local circuits. We investigated possible mechanisms that could underlie the single-spiking nature of the M-cell. We first assessed the involvement of the DTX-sensitive potassium conductance, which has been shown to contribute to single spiking in central auditory neurons of mammals and birds (Brew and Forsythe, 1995; Rathouz and Trussell, 1998; Bal and Oertel, 2001; Dodson et al., 2002). DTX is a selective blocker of voltage-gated potassium channels composed of subunits from the Kv1 family (Hopkins et al., 1994; Harvey, 1997, 2001). During application of DTX-I $(1 \mu \mathrm{M})$ to the brain surface, depolarization of the $\mathrm{M}$-cell resulted in repetitive firing at frequencies increased with the amplitude of the injected current (Fig. 8A1 vs B1) (10 cells). The time-to-spike peak of each action potential from the onset of the stepwise depolarization in the absence or presence of
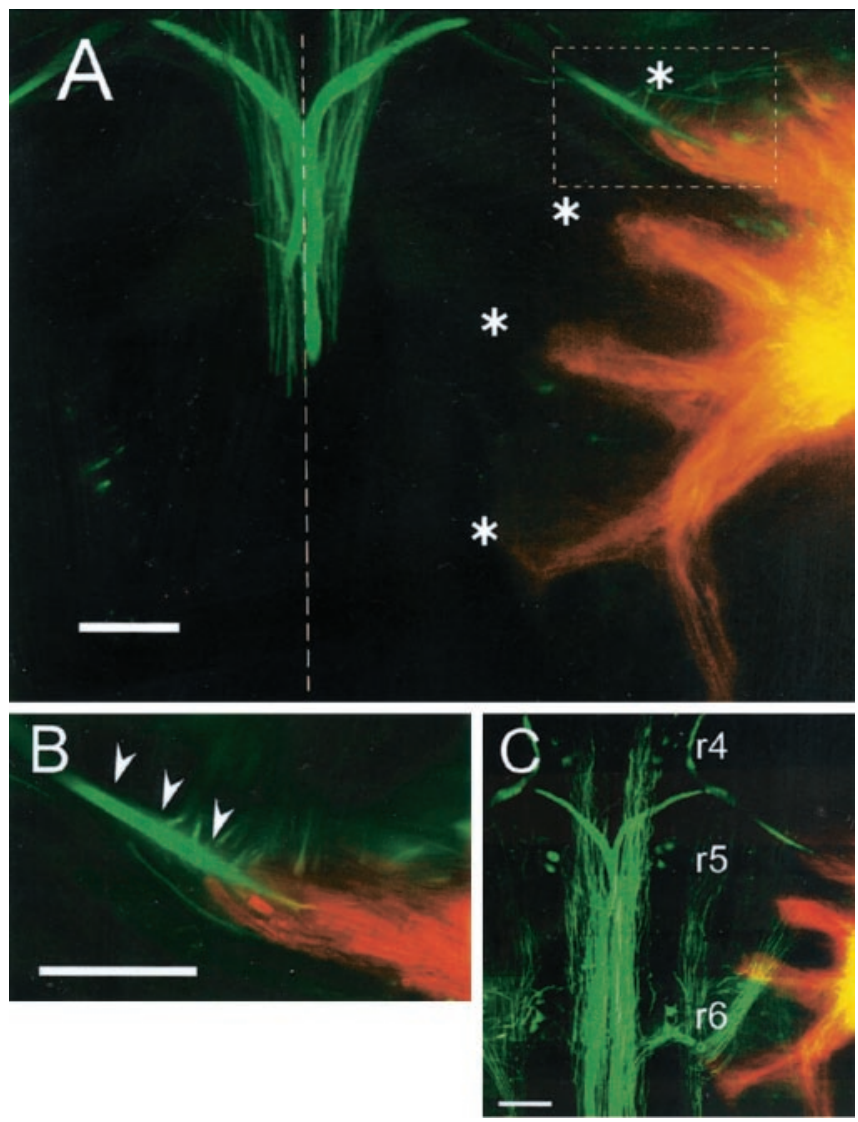

Figure 5. Labeling of pVIIIn and RS neurons. RS neurons (green) and pVIIIn (orange) were labeled with Oregon Green 488 and Dil, respectively. A, Two adjacent $80 \mu \mathrm{m}$ sections were superimposed where axons and lateral dendrites of bilateral M-cells (green) and right pVIIIn (orange) were labeled. Four fascicles of pVIIIn (asterisks) were observed to project medially to where lateral dendrites of the M-series neurons likely exist (compare Fig. 3). The first bundle projected to the vicinity of the distal region of the $\mathrm{M}$-cell lateral dendrite. The second and fourth bundles appeared to project into $r 5$ and $r 6$, respectively (also see $C$ ). Another bundle descending along the lateral edge of the brain was labeled. The dashed line indicates the midline. $B$, Highermagnification image of the inset in $A$. The pVIIIn afferents appeared to contact the distal part of the M-cell lateral dendrite (arrowheads). C, Eight serial sections were superimposed, including two dorsal sections shown in $A$. Somata of dorsal RS neurons in $r 4-r 6$ were labeled. Rostral is up. Scale bars, $200 \mu \mathrm{m}$.

DTX-I was plotted in Figure 8, A2 and B2, respectively. During DTX-I application, the M-cell showed initial spiking followed by repetitive firing after a brief pause (Fig. $8 B 1, B 2$ ).

The timing of this pause in firing corresponded to the duration of the recurrent IPSP (Fig. 8A3,B3), estimated from its shunting effect on the AD spike, as shown previously (Furukawa and Furshpan, 1963; Faber and Korn, 1982; Oda et al., 1995). The accuracy of this estimate is supported by the fact that the $\mathrm{AD}$ spike of the M-cell propagates passively into the soma and dendrites (Furshpan and Furukawa, 1962). The data suggest that the inhibitory conductance suppresses action potentials after the initial spiking of M-cell. Therefore, we examined the effect of blocking the recurrent inhibition on M-cell firing (Fig. 9). When strychnine $(100 \mu \mathrm{M})$ and bicuculline $(100 \mu \mathrm{M})$, antagonists of glycine and GABA receptors, respectively, were applied to the brain surface, the recurrent inhibition was abolished (Fig. 9A3), and $\mathrm{M}$-cells produced a short, transient burst at the onset of the depolarization (Fig. 9A1,A2) (five cells). The burst adapted within $10 \mathrm{msec}$, and no additional spike followed. The short burst was probably a result of intrinsic membrane properties of the 


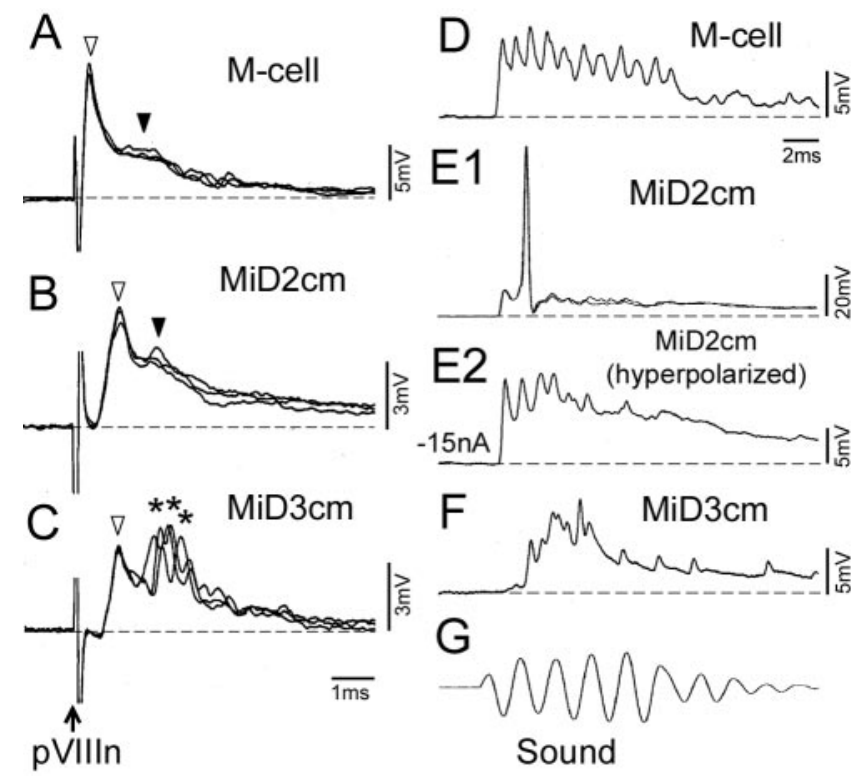

Figure 6. Synaptic responses evoked in M-series neurons by auditory stimulation. $A-C$, Postsynaptic potentials evoked in an $\mathrm{M}$-cell, a MiD2 $\mathrm{cm}$, and a MiD3 $\mathrm{cm}$, respectively, by electrical stimulation of pVIIIn. A, Depolarizing responses elicited in the M-cell had two components, indicated by open and filled arrowheads, that have been established to be mediated by electrical and glutamatergic synapses, respectively. $E_{\text {rest }}-82 \mathrm{mV}$. $B$, Depolarizing potentials of the MiD2cm consisted of two components: fast potentials (open arrowhead) with a constant onset latency followed by slow potentials (filled arrowhead). $E_{\text {rest }},-73 \mathrm{mV}$. C, Depolarizing potentials induced in the MiD $3 \mathrm{~cm}$ consisted of fast potentials (open arrowhead) with delayed but locked-in onset followed by fluctuating fast potentials (asterisks). $E_{\text {rest }}-78 \mathrm{mV}$. Dashed lines represent the baseline. $D-F$, Postsynaptic potentials induced by sound $(500 \mathrm{~Hz}, 95-100 \mathrm{~dB})(G)$ in M-series neurons different from $A-C$. D, Sharp depolarizing potentials were evoked in the M-cell. $E_{\text {rest }},-78 \mathrm{mV}$. E1, An action potential from an $E_{\text {rest }}$ of $-77 \mathrm{mV}$ was elicited in the MiD2cm. E2, Depolarizing potentials with sharp peaks were observed when the membrane was hyperpolarized by passing cathodal current $(-15 \mathrm{nA}) . F$, Delayed responses were observed in the $M i D 3 \mathrm{~cm} . E_{\text {rest }},-75 \mathrm{mV}$. The time scales in $($ and $D$ apply to $A-C$ and $D-G$, respectively.

M-cell, because similar strong adaptation was observed when most synaptic transmission was blocked by extracellular application of strychnine, bicuculline, DNQX, D-APV, D-3-(2carboxypiperazin-4-yl)-propyl-1-phosphonic acid, and D-tubocurarine (data not shown) (five cells). Finally, we blocked both the recurrent inhibition and the DTX-I-sensitive potassium channels by applying strychnine, bicuculline, and DTX-I. Under this condition, the M-cell generated uninterrupted repetitive firing with an initial adaptation followed by regular spiking (Fig. $9 B 1, B 2)(10$ cells). The frequency of this regular spiking increased as the cell was more depolarized (Fig. 9B2). Together, these data indicate that in the M-cell, DTX-I-sensitive potassium conductance prevents tonic repetitive firing, and that the recurrent inhibition suppresses the initial burst, permitting only a single spike at the onset of depolarization.

\section{Expression of Kv1.2 $\alpha$-subunit proteins on the M-cell}

The differences in firing properties between the M-cell and its homologs, MiD2 $\mathrm{cm}$ and MiD3cm, imply that they express different types of voltage-gated potassium channels. Because voltagegated potassium channels containing a Kv1.2 $\alpha$-subunit are sensitive to DTX-I (Hopkins et al., 1994; Harvey, 2001), we investigated the expression of the Kv1.2 $\alpha$-subunit in the goldfish hindbrain with immunohistochemistry. As shown in Figure 10, the soma and dendrites of $\mathrm{M}$-cells were immunoreactive to the anti-Kv1.2 antibody (Fig. 10A-F) (12 fish), although its axon was labeled only faintly. In control experiments in which the primary

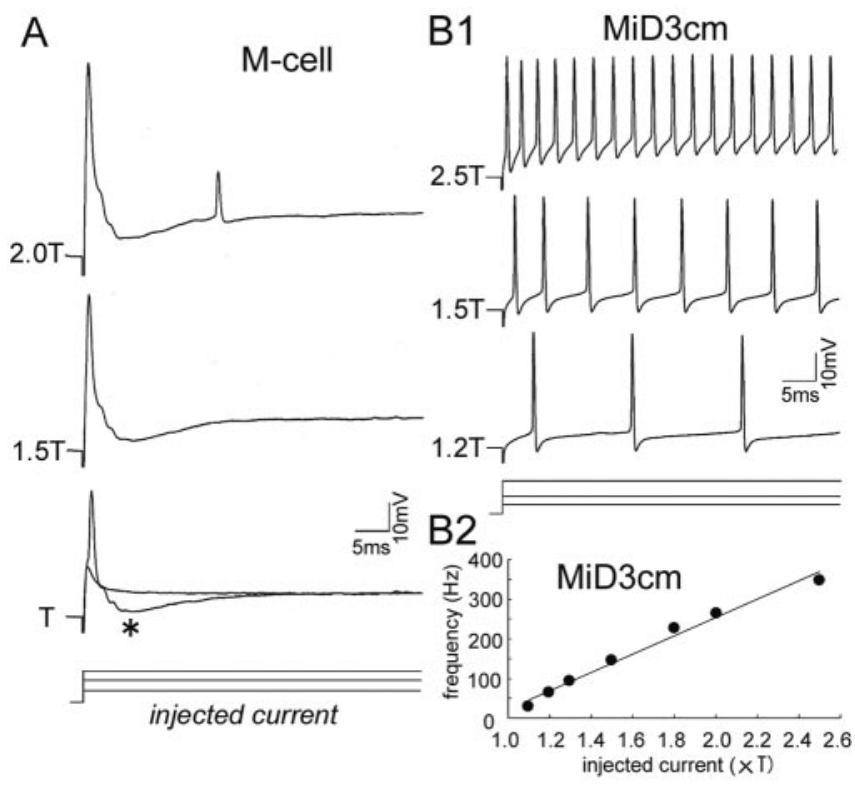

Figure 7. Different patterns of firing elicited by stepwise depolarization. A, Stepdepolarizing currents were injected into an M-cell soma through one of the two channels of $\theta$ microelectrode, and voltage responses were recorded with the other channel. A single action potential was elicited in response to threshold current intensity (T, $120 \mathrm{nA}$ in this cell) and 1.5T. The recurrent IPSPs (asterisk) were visible as hyperpolarizing potentials after the initial spike. An additional spike was elicited after the IPSPs at 2T. The amplitude of the first spike in each trace included capacitive transient potentials caused by an incomplete compensation of a coupling capacitance between two channels of a $\theta$ micropipette. $B 1$, Repetitive firing was elicited in a MiD3 $\mathrm{cm}$ by injection of much smaller currents than the $M$-cell $(T, 10 \mathrm{nA})$. The MiD $3 \mathrm{~cm}$ spiked with almost regular frequencies proportional to the injected currents. Note that there was no sign of the recurrent IPSPs after the spikes. $B 2$, Relationship between injected current and mean firing frequency of the $M i D 3 \mathrm{~cm}$ shown in $B 1$. The firing frequency increased almost linearly with the amplitude of the injected current; the slope was $23.1 \mathrm{~Hz} / \mathrm{nA}$.

antibodies were omitted or preabsorbed with antigenic protein, all of the labeling was abolished. In contrast to the M-cell, dorsal RS neurons in $\mathrm{r} 4-\mathrm{r} 6$, including $\mathrm{MiD} 2 \mathrm{~cm}$ and $\mathrm{MiD} 3 \mathrm{~cm}$, were not immunopositive for Kv1.2 (Fig. 10G-I). These observations suggest that voltage-gated potassium channels containing Kv1.2 $\alpha$-subunits are expressed in the M-cell but not in the homologs of the M-cell. In addition, afferent fibers apposed to distal lateral dendrite of the M-cells (Fig. 10A,B, asterisks) and some axons in the mlf were also labeled (Fig. $10 G-I$ ).

\section{Discussion}

We investigated how the M-series neurons obtain different electrophysiological properties and are incorporated into the hindbrain neuronal circuits in the adult teleost. The functional similarities and differences are schematically summarized in Figure 11. Although all of the M-series neurons received excitatory inputs from the pVIIIn afferents in parallel, as demonstrated both morphologically and electrophysiologically, they showed different firing patterns in response to stepwise depolarization. Both $M i D 2 \mathrm{~cm}$ and $M i D 3 \mathrm{~cm}$ produced tonic firings, whereas the M-cell showed typically phasic onset firing with a single spike. This unique feature of the M-cell was controlled by a combination of DTX-I-sensitive potassium conductance and recurrent inhibition. The present study has clarified the sensory afferent projections and output firing properties of the M-series, which have been suggested to work as a functional group during escape (Foreman and Eaton, 1993; O’Malley et al., 1996; Liu and Fetcho, 1999). 
A1

$$
\text { Control }
$$
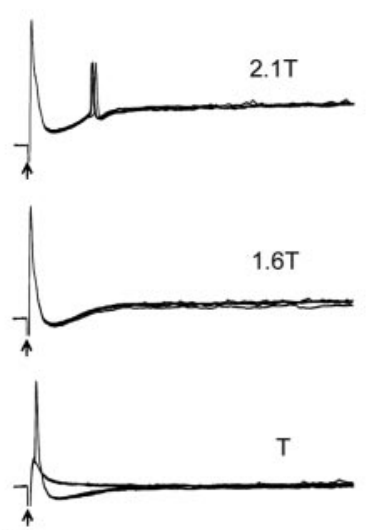

A2

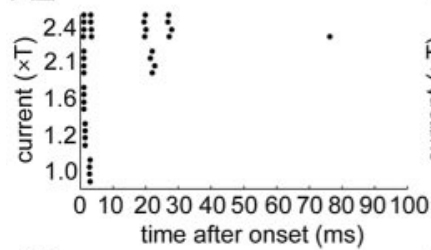

A3

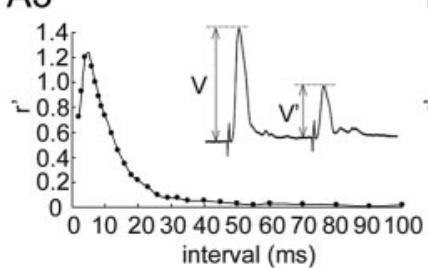

Figure 8. Effects of DTX-I on the firing of M-cell. Depolarization-induced firing of an M-cell before $(A)$ and during $(B)$ the application of DTX-I $(1 \mu \mathrm{M})$ to the brain surface. $A 1$, An action potential followed by recurrent IPSPs was elicited by stepwise depolarization with intensities of $\mathrm{T}(80 \mathrm{nA})$ and 1.6T stimulus. The onset of step currents was denoted by arrows (also in Fig. 9). An additional action potential was elicited after the recurrent IPSPs in response to a stronger stimulus (2.1T). Four responses were superimposed for each (also in B1). A2, Raster plots showing the peak time of each action potential from the onset of current pulse. One or two action potentials were evoked at the onset of stepwise depolarization. Additional spikes were observed, but after $\sim 15 \mathrm{msec}$ intervals from the initial firing in response to $>2 T$ depolarization. $A 3$, Synaptic conductance underlying the recurrent IPSPS $\left(G_{I P S P}\right)$ was estimated from its shunting effect on the test $A D$ spikes, which were applied after the control $A D$ spike at various interspike intervals (inset). Relative synaptic conductance $\left(r^{\prime}=G_{\text {IPSP }} / G_{m}\right.$, where $G_{m}$ is the resting conductance) was calculated from amplitude of the control $(V)$ and shunted $\left(V^{\prime}\right)$ AD spikes as $r^{\prime}=\left(V / V^{\prime}-1\right) \cdot B 1$, In the presence of DTX-I, the M-cell fired repetitively (1.5T and 2T). The threshold current intensity for spike generation (T, $40 \mathrm{nA})$ was lower than control. B2, Raster plots showed that the firing rate of the $\mathrm{M}$-cell increased with the degree of depolarization, and that there was a pause after the onset firing. B3, Recurrent inhibition in the presence of DTX-I. The time course of the $r^{\prime}$ was not affected by DTX-I, although the amplitude was slightly increased. $E_{\text {rest }}$ was stable at $-75 \mathrm{mV}$ throughout the experiment.

\section{The M-series neurons receive inputs from pVIIIn afferents in parallel}

The present study shows segmental organization of the pVIIIn afferents in the hindbrain (Fig. 5A-C), as observed previously in the anterior VIIIn afferents in frogs projecting into r5-r7 (Straka et al., 2001). It remains unclear from the morphological analysis (Fig. 5A) whether the pVIIIn afferents directly contact the $\mathrm{MiD} 2 \mathrm{~cm}$ and $\mathrm{MiD} 3 \mathrm{~cm}$, because their lateral dendrites could not be traced, presumably because of the small diameters of their dendrites. However, the fast EPSPs with short and constant latencies $(0.5 \mathrm{msec})$ elicited in the MiD2 $\mathrm{cm}$ by electrical stimulation of the pVIIIn (Fig. $6 B$ ) as well as the fast depolarization recorded in response to tone bursts (Fig. 6E2) imply a direct,

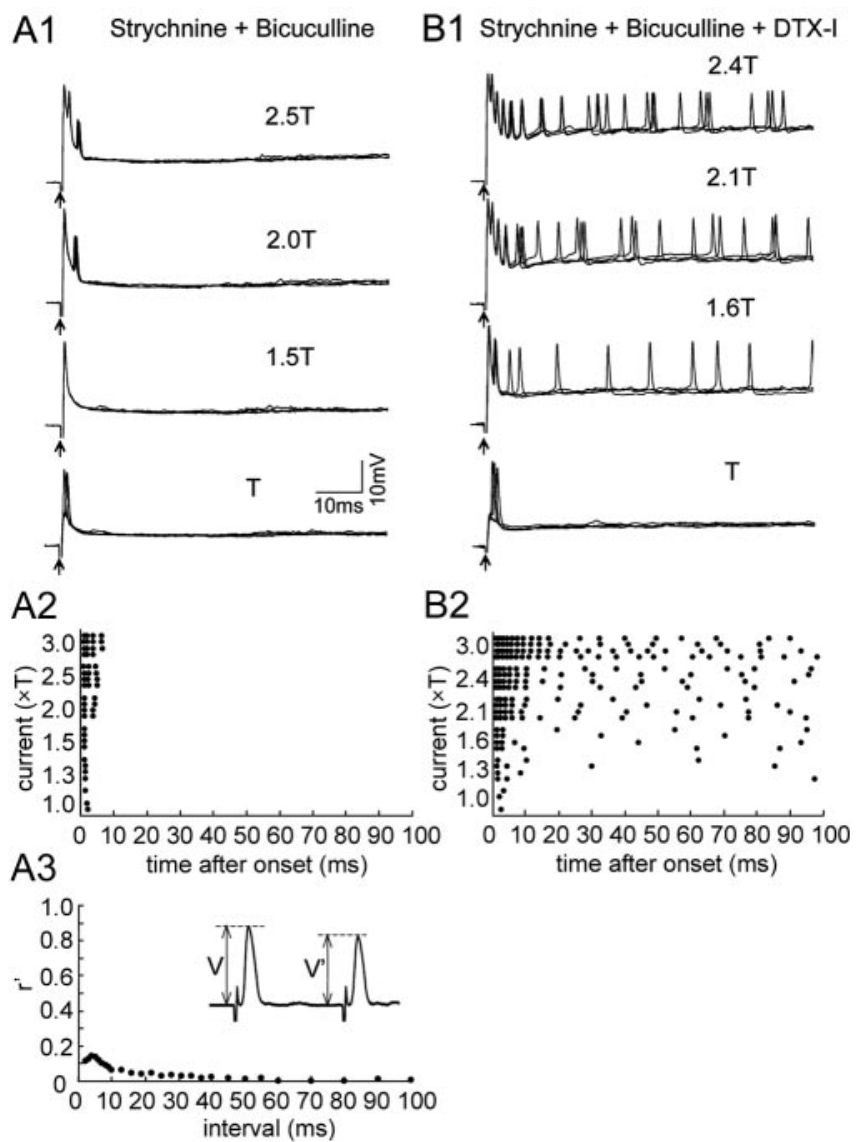

Figure 9. Effects of applying DTX-I and blocker for the recurrent inhibition of M-cell firing. Voltage responses of an M-cell in the presence of strychnine and bicuculline $(A)$ and during an additional application of DTX-I, DNQX, and APV ( $B$ ) are shown. $A 1$, An action potential without recurrent IPSPs was elicited by $\mathrm{T}(80 \mathrm{nA})$ and $1.5 \mathrm{~T}$ stimulus during application of strychnine (100 $\mu \mathrm{M})$ and bicuculline $(100 \mu \mathrm{M})$ to the brain surface. Short, transient spike bursts were evoked at the onset of depolarization (2T, 2.5T). Four responses were overlaid for each (also in $B 1$ ). $A 2$, Raster plots represent the peak time of each action potential. $A 3$, The synaptic conductance of the recurrent inhibition was abolished by strychnine and bicuculline, as shown in the inset. $B 1$, Continuous repetitive firings were induced during an additional application of DTX-I $(1 \mu \mathrm{M})$ $(1.6 \mathrm{~T}, 2.1 \mathrm{~T}$, and 2.4T; T, $70 \mathrm{nA})$. DNQX (200 $\mu \mathrm{m})$ and D-APV (1 mM) were also applied to block most of the synaptic transmission. $B 2$, Raster plots showed that continued, repetitive firing was induced. The firing frequency was higher during the initial $20 \mathrm{msec}$ than during the next phase. $E_{\text {rest }}$ in $A$ and $B$ was -78 and $-74 \mathrm{mV}$, respectively.

electrical connection from the pVIIIn afferents rather than indirect connections mediated by the unknown interneurons. Notably, the onset latency of the MiD2 $\mathrm{cm}$ was longer than that of the M-cell $(0.2 \mathrm{msec})$ (Fig. 6A). The longer latency of the MiD2cm indicates that it received connections from slower-conducting afferent fibers than those of the M-cell, because the conduction lengths to the M-cell and to MiD2 $\mathrm{cm}$ from the stimulation site were approximately the same (Fig. 5A). The pVIIIn contains two types of fibers, called S1 and S2 fibers, the diameters of which are $\sim 15$ and $5 \mu \mathrm{m}$ (Furukawa and Ishii, 1967), respectively; S1 fibers are thought to synapse on the M-cell lateral dendrite (Furukawa and Ishii, 1967; Nakajima, 1974; Tuttle et al., 1986). Assuming that the conduction velocity of the afferent fiber is proportional to its diameter, the longer onset latency of the EPSPs evoked in the MiD2 $\mathrm{cm}$ ( 0.5 vs $0.2 \mathrm{msec}$ ) could be caused by electrical synapses onto the MiD2 $\mathrm{cm}$ by S2 fibers. A difference in the types of pVIIIn afferents contacting the M-cell and its homologs is also indicated from the expression pattern of Kv1.2 (Fig. 10). The Kv1.2-immunopositive fibers terminating on the M-cell distal 

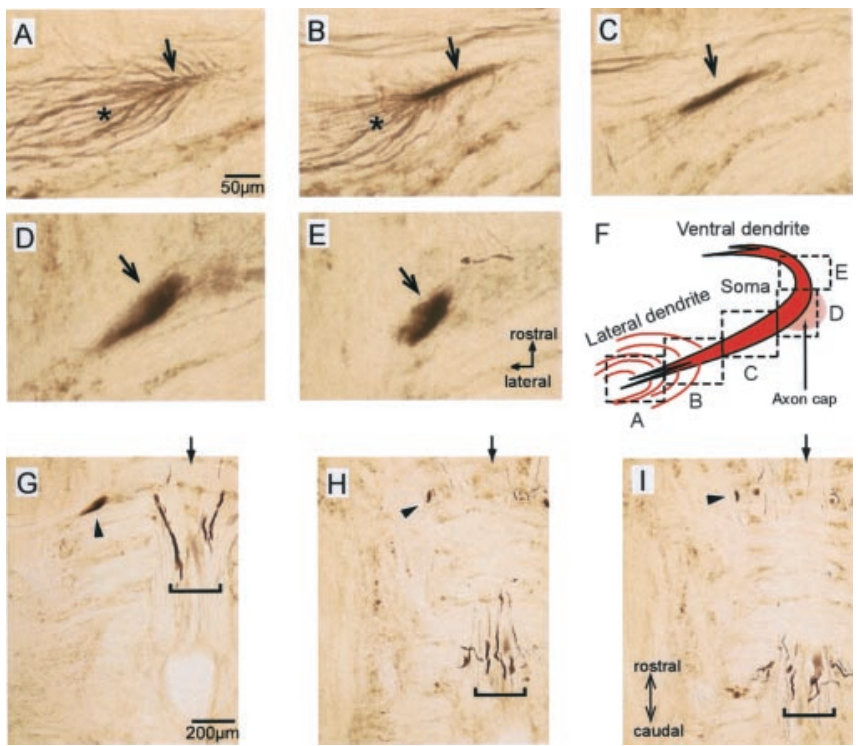

Figure 10. Immunostaining for Kv1.2 subunit in soma and dendrite of M-cell. Polyclonal anti-rat Kv1.2 antibody (Alomone Labs) was used. $A-E$, Serial horizontal sections with $50 \mu \mathrm{m}$ thickness where the lateral dendrite ( $A-C$, arrows), soma ( $D$, arrow), and proximal ventral dendrite ( $E$, arrow) of the $\mathrm{M}$-cell were immunolabeled. Fibers that appeared to connect to the distal lateral dendrite were also immunolabeled ( $A, B$, asterisks). $F$, Viewing fields in $A-E$. $G-I$, Horizontal sections of hindbrain, including the labeled M-cell (arrowheads). The soma of the $M$-cell was observed in $G$, and the ventral dendrite of the $M$-cell was observed in $H$ and $I$. $H$ and I were 100 and $150 \mu \mathrm{m}$ ventral to $G$, respectively. Dorsal RS neurons caudal to the M-cell, including $M i D 2 \mathrm{~cm}$ and $M i D 3 \mathrm{~cm}$, were not labeled. Some mlf fibers were labeled (brackets). Arrows indicate the midline.

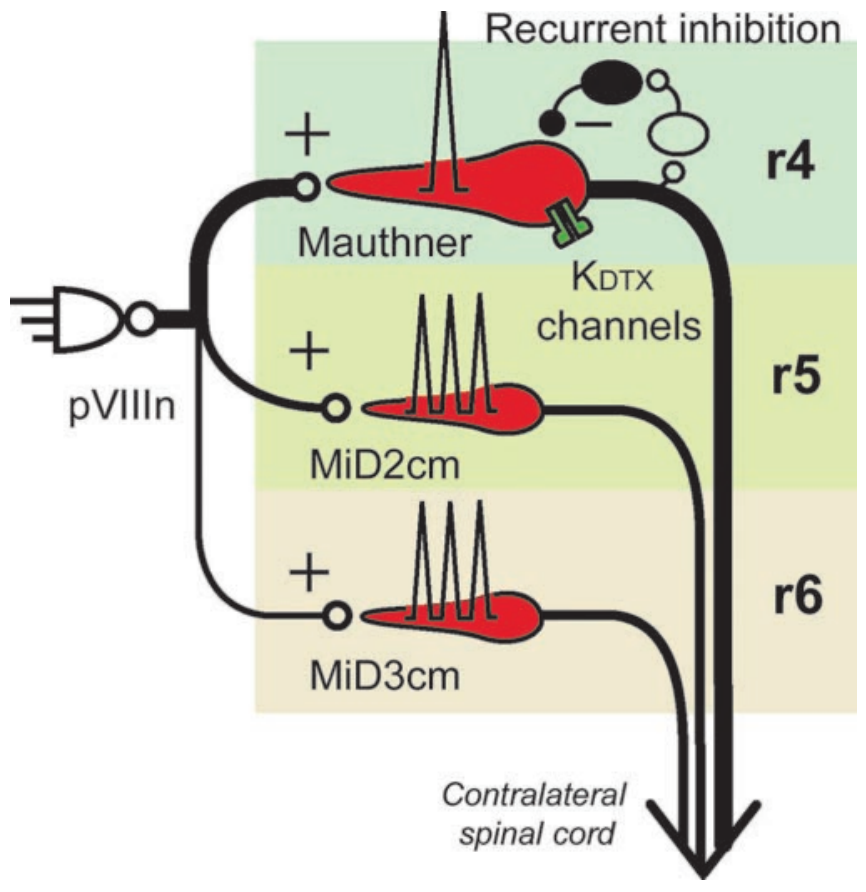

Figure 11. Functional similarities and differences among segmentally homologous RS neurons, the M-series. The thicker lines represent faster-conducting pathways. Open and filled circles indicate excitatory and inhibitory synapses, respectively. All M-series neurons are excited by the pVIIIn afferents. The M-cell only produces an action potential at the onset of a depolarization, in strong contrast to its serial homologs, MiD2 $\mathrm{cm}$ and $M i D 3 \mathrm{~cm}$, which fire repetitively. The unique firing property of the M-cell is attained by both DTX-I-sensitive, voltage-gated potassium channels $\left(K_{\mathrm{DTX}}\right)$ and the recurrent inhibition. lateral dendrite (Fig. 10A,B) are likely to be pVIIIn afferents on the basis of their location (Fig. 5A,B) (Faber and Korn, 1978; Lin et al., 1983; Pereda et al., 1995). In contrast, those projecting into r5 or r6 (Fig. 5A) did not appear to be labeled by the Kv1.2 antibody. Thus, the $\mathrm{M}$-cell and its homologs may receive inputs from different types of pVIIIn afferents.

\section{Mechanisms underlying onset, single spiking of the M-cell, and its function}

There is a striking difference in the firing properties of the $\mathrm{M}$-series neurons. Especially obvious is the phasic spiking of the M-cell. Some neurons in the auditory pathway of mammals and birds also generate a single spike at the onset of depolarization. Blocking low-threshold potassium channels with DTX transforms the firing pattern of these neurons from phasic to tonic (Brew and Forsythe, 1995; Rathouz and Trussell, 1998; Bal and Oertel, 2001; Dodson et al., 2002). Similarly under DTX-I application, the M-cell fired repetitively during current injection, except for a pause caused by recurrent inhibition (Fig. 8B-B3). Thus, the single onset firing observed in controls is at least partly attributable to the activation of the DTX-I-sensitive potassium channels rather than the inactivation of the sodium channels that was observed in the teleost thalamic neurons (Tsutsui and Oka, 2002). We can exclude the possibility that the repetitive firing during DTX-I application is a result of increased circuit excitability for the following reasons. First, recurrent inhibition of the M-cell appeared normal (Fig. 8 B3). Second, the DTX-I-induced repetitive firing was also observed in the presence of blockers for most excitatory synapses (DNQX and APV; data not shown) or for both excitatory and inhibitory synapses (Fig. 9B1,B2). These observations indicate that the locus of the DTX-I effect is in the $\mathrm{M}$-cell itself. If the DTX-I-sensitive potassium conductance in the $\mathrm{M}$-cell was activated around resting membrane potentials, it could also contribute to the high threshold of the M-cell by repolarizing membrane potential and lowering input resistance.

DTX-I is a selective blocker of potassium channels that contain mammalian Kv1.1, Kv1.2, or Kv.1.6 $\alpha$-subunits (Hopkins et al., 1994; Harvey, 1997). Little is known about the molecular structure and tissue expression of potassium channels in the fish brain. However, $\alpha$-subunit 1 of Shaker-related trout CNS potassium channel (Tsha1) has been shown recently to be a fish homolog of rat Kv1.2 $\alpha$-subunit and forms low threshold, delayed rectifier potassium channels sensitive to DTX (Nguyen and Jeserich, 1998; Nguyen et al., 2000). The C-terminal region of rat Kv1.2 used for generating the antibody shares high sequence similarity with that of Tshal (Nguyen et al., 2000), indicating a likelihood of cross-reactivity. In this study, we demonstrated that the M-cell was immunoreactive for an anti-rat Kv1.2 antibody (Fig. 10). These results suggest that the DTX-I-sensitive potassium channels, responsible for the phasic spiking of the M-cell, may contain Tshal subunits.

Single spiking of the M-cell seems sufficient or critical for initiating normal fast C-starts from the following observations. First, a single spike of an M-cell is associated with the initiation of a C-start in goldfish (Zottoli, 1977; Eaton et al., 1982) and is sufficient to induce the initial part of the behavior (Nissanov et al., 1990). Second, repetitive firing of M-cells was not observed in zebrafish exhibiting matured escape (Kimmel et al., 1974; Eaton and Farley, 1975), whereas more than one spike was observed in young embryos performing immature behavior (Eaton et al., 1977). Third, spurious fast double turns were observed in zebrafish space cadet mutants in which the M-cell excitability was assumed to be increased (Lorent et al., 2001). 


\section{Physiological importance of the segmentally homologous neurons}

This study supports the idea that the M-series contributes to fish escape behaviors (Foreman and Eaton, 1993; O'Malley et al., 1996; Liu and Fetcho, 1999) evoked by auditory stimuli. In addition, our study indicates that different $\mathrm{M}$-series neurons convey different aspects of sensory inputs to the spinal cord, because they show different excitabilities and postsynaptic responses to auditory stimuli. Recent morphological observations in zebrafish showed a diversity of arborization patterns for axon collaterals of the M-series neurons in the spinal cord (Gahtan and O'Malley, 2003). The M-cell has short knob-like collaterals restricted to the side ipsilateral to its stem axon, whereas MiD2 $\mathrm{cm}$ and $\mathrm{MiD} 3 \mathrm{~cm}$ have axon collaterals with extensive branching in the spinal cord. Furthermore, the collaterals of MiD2 cm terminate bilaterally. These distinctive arborization patterns suggest that they synapse on different types of neurons. These physiological and morphological differences among the $\mathrm{M}$-series neurons indicate that they play different roles in initiating and controlling the escape behavior. The lower firing threshold of $\mathrm{MiD} 2 \mathrm{~cm}$ to auditory stimuli than that of the M-cell may imply that $\mathrm{MiD} 2 \mathrm{~cm}$ can transmit subthreshold sound information to preshape or modify the spinal activity before escape.

It is believed that the M-cell plays a key role in initiating fast escape responses (Zottoli, 1977; Eaton et al., 1981; Hackett and Greenfield, 1986, 1988; Nissanov et al., 1990). However, it has been demonstrated that fish still perform escape after M-cells have been abolished, although in many cases, the onset is delayed (Eaton et al., 1982; Kimmel et al., 1982; DiDomenico et al., 1988; Liu and Fetcho, 1999; Zottoli et al., 1999). This observation suggested the presence of alternative circuits to initiate the escape independent of the M-cells. MiD2 $\mathrm{cm}$ and $\mathrm{MiD} 3 \mathrm{~cm}$ have been proposed to play a dedicated role in the alternative network (Liu and Fetcho, 1999) as well as in the intact escape network (O'Malley et al., 1996), although many other neurons might also be involved (Bosch et al., 2001; Gahtan et al., 2002). It would be a fascinating idea if the alternative network were suppressed by the M-cell-initiated escape networks, as proposed previously (Nissanov et al., 1990). If that is the case, it is possible that MiD2 cm and $\mathrm{MiD} 3 \mathrm{~cm}$ contribute differently to the escape behavior in the presence and absence of the M-cells. Therefore, the next step for understanding the physiological importance of the M-series neurons in escape networks would be to study mutual connections among the M-series neurons in both intact and M-cell-ablated animals.

\section{References}

Bal R, Oertel D (2001) Potassium currents in octopus cells of the mammalian cochlear nucleus. J Neurophysiol 86:2299-2311.

Bosch TJ, Maslam S, Roberts BL (2001) Fos-like immunohistochemical identification of neurons active during the startle response of the rainbow trout. J Comp Neurol 439:306-314.

Brew HM, Forsythe ID (1995) Two voltage-dependent $\mathrm{K}^{+}$conductances with complementary functions in postsynaptic integration at a central auditory synapse. J Neurosci 15:8011-8022.

Canfield JG, Eaton RC (1990) Swimbladder acoustic pressure transduction initiates Mauthner-mediated escape. Nature 347:760-761.

Casagrand JL, Guzik AL, Eaton RC (1999) Mauthner and reticulospinal responses to the onset of acoustic pressure and acceleration stimuli. J Neurophysiol 82:1422-1437.

Diamond J, Huxley AF (1968) The activation and distribution of GABA and L-glutamate receptors on goldfish Mauthner neurones: an analysis of dendritic remote inhibition. J Physiol (Lond) 194:669-723.

DiDomenico R, Nissanov J, Eaton RC (1988) Lateralization and adaptation of a continuously variable behavior following lesions of a reticulospinal command neuron. Brain Res 473:15-28.
Dodson PD, Barker MC, Forsythe ID (2002) Two heteromeric Kv1 potassium channels differentially regulate action potential firing. J Neurosci 22:6953-6961.

Eaton RC, Farley RD (1975) Mauthner neuron field potential in newly hatched larvae of the zebra fish. J Neurophysiol 38:502-512.

Eaton RC, Farley RD, Kimmel CB, Schabtach E (1977) Functional development in the Mauthner cell system of embryos and larvae of the zebra fish. J Neurobiol 8:151-172.

Eaton RC, Lavender WA, Wieland CM (1981) Identification of Mauthnerinitiated response patterns in goldfish: evidence from simultaneous cinematography and electrophysiology. J Comp Physiol [A] 144:521-531.

Eaton RC, Lavender WA, Wieland CM (1982) Alternative neural pathways initiate fast-start responses following lesions of the Mauthner neuron in goldfish. J Comp Physiol [A] 145:485-496.

Eaton RC, DiDomenico R, Nissanov J (1988) Flexible body dynamics of the goldfish C-start: implications for reticulospinal command mechanisms. J Neurosci 8:2758-2768.

Faber DS, Korn H (1978) Electrophysiology of the Mauthner cell: basic properties, synaptic mechanisms, and associated networks. In: Neurobiology of the Mauthner cell (Faber DS, Korn H, eds), pp 47-131. New York: Raven.

Faber DS, Korn H (1982) Transmission at a central inhibitory synapse. I. Magnitude of unitary postsynaptic conductance change and kinetics of channel activation. J Neurophysiol 48:654-678.

Faber DS, Korn H, Lin JW (1991) Role of medullary networks and postsynaptic membrane properties in regulating Mauthner cell responsiveness to sensory excitation. Brain Behav Evol 37:286-297.

Fay RR (1995) Physiology of primary saccular afferents of goldfish: implications for Mauthner cell response. Brain Behav Evol 46:141-150.

Fetcho JR, Faber DS (1988) Identification of motoneurons and interneurons in the spinal network for escapes initiated by the Mauthner cell in goldfish. J Neurosci 8:4192-4213.

Foreman MB, Eaton RC (1993) The direction change concept for reticulospinal control of goldfish escape. J Neurosci 13:4101-4113.

Furshpan EJ (1964) Electrical transmission at an excitatory synapse in a vertebrate brain. Science 144:878-880.

Furshpan EJ, Furukawa T (1962) Intracellular and extracellular responses of the several regions of the Mauthner cell of the goldfish. J Neurophysiol 25:732-771.

Furukawa T, Furshpan EJ (1963) Two inhibitory mechanisms in the Mauther neurons of goldfish. J Neurophysiol 26:140-176.

Furukawa T, Ishii Y (1967) Neurophysiological studies on hearing in goldfish. J Neurophysiol 30:1377-1403.

Furukawa T, Fukami Y, Asada Y (1964) Effects of strychnine and procaine on collateral inhibition of the Mauthner cell of goldfish. Jpn J Physiol 14:386-399.

Gahtan E, O'Malley DM (2003) Visually guided injection of identified reticulospinal neurons in zebrafish: a survey of spinal arborization patterns. J Comp Neurol 459:186-200.

Gahtan E, Sankrithi N, Campos JB, O’Malley DM (2002) Evidence for a widespread brain stem escape network in larval zebrafish. J Neurophysiol 87:608-614.

Hackett JT, Greenfield LJ (1986) The behavioral role of the Mauthner neuron impulse. Behav Brain Sci 9:729-730.

Hanneman E, Westerfield M (1989) Early expression of acetylcholinesterase activity in functionally distinct neurons of the zebrafish. J Comp Neurol 284:350-361.

Hanneman E, Trevarrow B, Metcalfe WK, Kimmel CB, Westerfield M (1988) Segmental pattern of development of the hindbrain and spinal cord of the zebrafish embryo. Development 103:49-58.

Harvey AL (1997) Recent studies on dendrotoxins and potassium ion channels. Gen Pharmacol 28:7-12.

Harvey AL (2001) Twenty years of dendrotoxins. Toxicon 39:15-26.

Hopkins WF, Allen ML, Houamed KM, Tempel BL (1994) Properties of voltage-gated $\mathrm{K}^{+}$currents expressed in Xenopus oocytes by mKv1.1, mKv1.2 and their heteromultimers as revealed by mutagenesis of the dendrotoxin-binding site in mKv1.1. Pflügers Arch 428:382-390.

Kimmel CB, Patterson J, Kimmel RO (1974) The development and behavioral characteristics of the startle response in the zebrafish. Dev Psychobiol 7:47-60. 
Kimmel CB, Powell SL, Metcalfe WK (1982) Brain neurons which project to the spinal cord in young larvae of the zebrafish. J Comp Neurol 205:112-127.

Lee RK, Eaton RC (1991) Identifiable reticulospinal neurons of the adult zebrafish, Brachydanio rerio. J Comp Neurol 304:34-52.

Lee RK, Eaton RC, Zottoli SJ (1993a) Segmental arrangement of reticulospinal neurons in the goldfish hindbrain. J Comp Neurol 329:539-556.

Lee RK, Finger TE, Eaton RC (1993b) GABAergic innervation of the Mauthner cell and other reticulospinal neurons in the goldfish. J Comp Neurol 338:601-611.

Lin JW, Faber DS (1988) Synaptic transmission mediated by single club endings on the goldfish Mauthner cell. I. Characteristics of electrotonic and chemical postsynaptic potentials. J Neurosci 8:1302-1312.

Lin JW, Faber DS, Wood MR (1983) Organized projection of the goldfish saccular nerve onto the Mauthner cell lateral dendrite. Brain Res 274:319-324

Liu KS, Fetcho JR (1999) Laser ablations reveal functional relationships of segmental hindbrain neurons in zebrafish. Neuron 23:325-335.

Lorent K, Liu KS, Fetcho JR, Granato M (2001) The zebrafish space cadet gene controls axonal pathfinding of neurons that modulate fast turning movements. Development 128:2131-2142.

McCormick CA, Braford Jr MR (1994) Organization of inner ear endorgan projections in the goldfish, Carassius auratus. Brain Behav Evol 43:189-205.

Mendelson B (1986a) Development of reticulospinal neurons of the zebrafish. I. Time of origin. J Comp Neurol 251:160-171.

Mendelson B (1986b) Development of reticulospinal neurons of the zebrafish. II. Early axonal outgrowth and cell body position. J Comp Neurol 251:172-184

Metcalfe WK, Mendelson B, Kimmel CB (1986) Segmental homologies among reticulospinal neurons in the hindbrain of the zebrafish larva. J Comp Neurol 251:147-159.

Nakajima Y (1974) Fine structure of the synaptic endings on the Mauthner cell of the goldfish. J Comp Neurol 156:379-402.

Nguyen TD, Jeserich G (1998) Molecular structure and expression of shaker type potassium channels in glial cells of trout CNS. J Neurosci Res 51:284-292.

Nguyen TD, Rabe H, Terlau H, Jeserich G (2000) Isolation and heterolo- gous expression of two genomic clones encoding Shaker-related potassium channels of trout CNS. J Neurosci Res 60:174-183.

Nissanov J, Eaton RC, DiDomenico R (1990) The motor output of the Mauthner cell, a reticulospinal command neuron. Brain Res 517:88-98.

Oda Y, Charpier S, Murayama Y, Suma C, Korn H (1995) Long-term potentiation of glycinergic inhibitory synaptic transmission. J Neurophysiol 74:1056-1074.

Oda Y, Kawasaki K, Morita M, Korn H, Matsui H (1998) Inhibitory longterm potentiation underlies auditory conditioning of goldfish escape behaviour. Nature 394:182-185.

O’Malley DM, Kao YH, Fetcho JR (1996) Imaging the functional organization of zebrafish hindbrain segments during escape behaviors. Neuron 17:1145-1155.

Pereda AE, Bell TD, Faber DS (1995) Retrograde synaptic communication via gap junctions coupling auditory afferents to the Mauthner cell. J Neurosci 15:5943-5955.

Rathouz M, Trussell L (1998) Characterization of outward currents in neurons of the avian nucleus magnocellularis. J Neurophysiol 80:2824-2835

Straka H, Baker R, Gilland E (2001) Rhombomeric organization of vestibular pathways in larval frogs. J Comp Neurol 437:42-55.

Triller A, Korn H (1981) Morphologically distinct classes of inhibitory synapses arise from the same neurons: ultrastructural identification from crossed vestibular interneurons intracellularly stained with HRP. J Comp Neurol 203:131-155.

Tsutsui H, Oka Y (2002) Slow removal of $\mathrm{Na}(+)$ channel inactivation underlies the temporal filtering property in the teleost thalamic neurons. J Physiol (Lond) 15:743-753.

Tuttle R, Masuko S, Nakajima Y (1986) Freeze-fracture study of the large myelinated club ending synapse on the goldfish Mauthner cell: special reference to the quantitative analysis of gap junctions. J Comp Neurol 246:202-211.

Waldeck RF, Pereda A, Faber DS (2000) Properties and plasticity of pairedpulse depression at a central synapse. J Neurosci 20:5312-5320.

Zottoli SJ (1977) Correlation of the startle reflex and Mauthner cell auditory responses in unrestrained goldfish. J Exp Biol 66:243-254.

Zottoli SJ, Newman BC, Rieff HI, Winters DC (1999) Decrease in occurrence of fast startle responses after selective Mauthner cell ablation in goldfish (Carassius auratus). J Comp Physiol [A] 184:207-218. 